\title{
Peran Strategis Public Relation dalam Pengembangan Reputasi Pendidikan Tinggi: Studi Kasus Promosi di Akademi Farmasi Surabaya
}

\author{
${ }^{1}$ Abd Syakur, ${ }^{2}$ Redi Panuju \\ ${ }^{1,2}$ Program Studi Magister Ilmu Komunikasi, Fakultas Ilmu Komunikasi, \\ Universitas Dr. Soetomo, Surabaya, Indonesia
}

Email: ${ }^{1}$ syakurabdmpd@gmail.com, ${ }^{2}$ redipanuju@gmail.com

Tersedia Online di

http://www.jurnal.unublitar.ac.id/ index.php/briliant

Sejarah Artikel

Diterima pada 9 Februari 2020

Disetuji pada 29 Februari 2020

Dipublikasikan pada 29 Februari

2020 Hal. 128-136

Kata Kunci:

$\overline{\text { Public relation; strategi; }}$ reputasi; Perguruan Tinggi

DOI:

http://dx.doi.org/10.28926/briliant .v3i4.439

\begin{abstract}
Abstrak: Public Relation (PR) memiliki peranan yang sangat fundamental dalam pengembangan reputasi pendidikan tinggi (PT). Tujuan penelitian ini adalah untuk menganalisis strategi PR (humas) dalam kegiatan promosi dan hubungannya dengan pengembangan reputasi perguruan tinggi di Akademi Farmasi Surabaya. Metode penelitian ini menggunakan non-eksperimental dengan pendekatan kuantitatif melalui rancangan korelasional. Data yang digunakan dalam penelitian ini adalah data primer yang analisis menggunakan Sofware SPSS 23. Parameter data yang di uji adalah kualitas, validitas dan reliabilitas data. Bila dari hasi uji memenuhi asumsi klasik akan dilanjutkan dengan pengujian regresi linier berganda. Hasil dari penelitian ini peran PR memiliki peranan strategis untuk kemajuan PT sebesar 0,449 dan 0,502. Manajemen dan strategi PR secara simultan berpengaruh terhadap promosi dengan minat mahasiswa baru di Akademi Farmasi Surabaya.
\end{abstract}

\section{PENDAHULUAN}

Globalisasi dunia pendidikan tinggi berdampak secara langsung pada persaingan yang semakin tajam antar perguruan tinggi khususnya di Indonesia. Persaingan ini bukan perguruan tinggi bukan hanya perguruan tinggi (PT) yang ada di indonesia saja, tetapi juga PT luar negeri dari manca negara (Salim, Sari, Islam, \& Riau, 2014; A. Syakur, 2017). Persaingan PT menuntut adanya perbaikan managemen dan kualitas PT, sehingga dapat bertahan dan bahkan dapat bersaing. Jumlah PT yang semakin banyak menjadi salah satu faktor meningkatnya persaingan antar PT dan hal ini menjadi ancaman terhadap PT yang kurang siap bersaing (Salim et al., 2014).

Persaingan antar PT yang skalanya bukanya hanya lokal tetapi skala internasional yang menjadi tantangan besar yang harus dihadapi dengan persiapan mutu yang baik.Perjalanan menuju persaingan tersebut tentu PT harus memperhatikan unsur kualitas dan kuantitas. Unsur ini menjadi sangat penting bagi PT sehingga keberlangsungan PT dapat eksis di masa yang akan datang (Dirgantari, 2012). Adanya kuantitas tidaklah cukup dalam menghadapai persaing antar PT, tetapi harus bersamaan dengan kualitas PT, maka keduanya menjadi 
faktor penting eksistensi PT. Hal yang menjadi masalah mendasar adalah optimalisasi kualitas dan kuantitas PT tidak menjadi hal yang utama dan bahkan hanya mengandalkan salah satu aspek dari kedua unsur tersebut (Kartikasari, 2014; Abd Syakur, 2018). Setiap PT agar dapat mempertahankan eksistensinya dan mampu berkembang, dibutuhkan eksplorasi terhadap faktor-faktor pendukung untuk dapat meningkatkan citra dan keunggulan bersaing PT (Arifin, 2017).

Menjalin hubungan dengan berbagai kalangan menjadi sangat penting untuk memberikan kontribusi modal sosial yang juga penting bagi penciptaan keunggulan kompetitif PT (Wijaya, 2015). Upaya menumbuhkan kepercayaan masyarakat terhadap PT dirasa harus melakukan hubungan dengan masyarakat yang lebih harmonis agar terbentuk persepsi positif masyarakat. Hal ini penting dalam konteks otonomi pendidikan masyarakat merupakan salah satu stakeholder yang mempunyai peran penting dalam memajukan sebuah PT (Lugi Basuki, 2016). Hubungan PT dengan masyarakat merupakan hal harus bangun secara profesional untuk mewujudkan citra positif PT (Dirgantari, 2016).

PR merupakan manajemen reputasi organisasi untuk melakukan identifikasi terhadap persepsi masyarakat serta memberi informasi terhadap kinerja PT kepada khalayak umum masyarakat (Lugi Basuki, 2016). Strategi merupakan hal yang penting dan sebagai petunjuk umu untuk mencapai tujuan jangka panjang PT (Nur Harini, 2014). Salah satu dampak dari adanya PR yang dilakukan oleh PT adalah terbentuknya informasi positif PT dari penilaian masyarakat luar. Institusi memberikan pelayanan prima dan hubungan komunikasi yang baik, sehingga terbentuknya kepercayaan masyarakat terhadap PT dan implikasinya adalah masyarakat benar-benar mendukung kemajuan PT.

Hubungan komunikasi antara PT dan masyarakat menghasilkan kepercayaan diatara keduanya, dengan demikian masyarakat dengan sendirinya akan tertarik masuk pada PT. PR adalah strategi komunikasi yang penting dana hal ini menjadi media untuk mencapai tujuan yang diinginkan di masa yang akan datang (Rahman, 2016; Abd Syakur, 2018). Efektivitas komunikasi merupakan hal yang sangat menentukan kesuksesan suatu organisasi dalam jangka pendek danjangka panjang. Maka dari itu hubungan masyarakat sangat diperlukan oleh sebuah PT dengan tujuan untuk mendapatkan keperrcayaan masyarakat. Berdasarkan uraian di atas bahwa hubungan peningkatan kualitas PT dalam hal ini Akademi Farmasi Surabaya dalam dengan strategi peningkatan reputasi PT.

\section{METODE}

\section{Lokasi Penelitian}

Penelitian ini dilakukan berdasarkan studi kasus pada stragi public relation dan managemen promosi Akademi Farmasi Surabaya. Penelitian ini dilakukan dengan menggunakan non eksperimental melalui pendekatan kuantitatif melalui rancangan korelasional.

\section{Metode Penelitian}

Metode ini tidak diperlakukan perlakuan (treatmen) terhadap variabelvariabel yang diukur. Dari sisi metode penelitian menggunakan pendekatan "oneshot" model. Penelitian merupakan jenis penelitian non-eksperimen, peneliti tidak memanipulasi variabel-variabel yang berhubungan atau dalam menetapkan suatu pristiwa atau keadaan yang sudah terjadi yang berhubungan dengan kondisi yang ada sekarang. Penilitian ini mendiskripsikan hubungan antara sejumlah faktor 
dengan faktor yang lainnya serta penelitian ini berusaha untuk menghubungkan suatu keadaan dengan beberapa aspek yang ada dan dianggap penting.

Jumlah sampel yang digunakan dalam obyek penelitian ini berjumlah 93 mahasiswa dan 40 Dosen di Akademi Farmasi Surabaya sehingga total keseluruhan sampel berjumlah 133 sampel.

\section{Data dan analisis data}

Data primer yang digunakan dengan cara mengisi kuisoner yang telah disiapkan oleh peneliti dan nantinya hasil pengembalian kuisoner yang sudah diisi tersebut akan digunakan sebagai data penelitian ini.

Teknik pengolahan data adalah mengumpulkan jawaban yang telah di isi dari kuesioner yang disebarkan pada responden yang dipilih secara acak. Pengolahan data pada penelitian ini menggunakan software SPSS 23. Pengujian pertama dilakukan uji kualitas data menggunakan uji validitas dan reliabilitas agar data digunakan sudah layak dilakukan analisis selanjutnya atau tidak. Kemudian dilakukan uji regresi linier berganda dimana menggunakan skor total dari masing-masing variabel. Variabel $\mathrm{X}$ adalah manajemen dan strategi PR sedangkan variabel $\mathrm{Y}$ adalah promosi penerimaan mahasiswa baru di perguruan tinggi. Sebelum diuji regresi linier berganda, terlebih dahulu diuji asumsi klasik yang terdiri dari uji normalitas, uji multikolinieritas, dan uji heteroskedastisitas. Apabila tidak memenuhi salah satu asumsi klasik tersebut, maka pengujian tidak dapat dilanjutkan ke regresi linier sederhana.

\section{Uji Kualitas Data}

Pengujian kualitas data menggunakan dua konsep yaitu malalui uji validitas dan uji reliabilitas. Pengujian tersebut bermksud untuk menghasilkan kesimpulan yang tidak bias.

\section{Uji Validitas Data}

Pengukuran validitas dapat dilakukan melalui cara melakukan korelasi antar skor butir pertanyaan dengan total skor konstruk atau variabel. Uji signifikansi dilakukan dengan membandingkan nilai $r$ hitung dengan $r$ tabel untuk degree of freedom $(\mathrm{df})=\mathrm{n}-2$, dalam ini $\mathrm{n}$ adalah jumlah sampel, dengan alpha sebesar 5\% dengan ketentuan sebagai berikut:

1. Jika $r_{\text {hitumg }}>$ r tabel (pada signifikansi 0,05), maka variabel tersebut valid.

2. Jika $r_{\text {hiturg }} \leqslant \mathrm{r}$ tabel (pada signifikansi 0,05 ), maka variabel tersebut tidak valid.

Bila $r$ hitung (setiap butir dapat dilihat pada colom corrected item - total correlation) lebih besar dari $\mathrm{r}$ tabel maka pernyataan tersebut dinyatakan valid.

\section{Uji Reliabilitas}

Reliabilitas merupakan indeks yang menunjukan sejauh mana suatu alat pengukur dapat dipercaya. Suatu alat pengukur dikatakan mantap atau konsisten, apabila untuk mengukur itu menunjukan hasil yang sama, dalam kondisi yang sama. Apabila nilai Cronbach Alpha lebih dari 0,6 maka dapat dikatakan bahwa sudah reliabel.

\section{HASIL DAN PEMBAHASAN}

\section{Peran PR terhadap managemen promosi Akademi Farmasi Surabaya}

Manajemen banyak diartikan sebagai ilmu dan seni dalam mencapai tujuan melalui kegiatan orang lain yang berarti manajemen dapat dilakukan apabila dalam pencapaian tujuan tersebut tidak hanya dilakukan oleh 
seseorang tapi juga oleh banyak orang (Arifin, 2017; Nur Harini, 2014). Fungsi manajemen adalah sebagai dasar dalam melakukan proses manajemen, ketika seorag manajer melakukan proses manajemen tidak terlepas dari fungsi manajemen itu sendiri yang didukung oleh sumber daya yang memiliki berkemampuan dan memadai (Priyatna, 2017).

Berdasarkan hasil penelitian menunjukkan bahwa peranan manajemen yang diberikan kepada responden diperoleh bahwa mayoritas memiliki nilai ratarata tertinggi 3,35 yang ada pada pernyataan, sedangkan secara keseluruhan manajemen memiliki nilai rata- rata sebesar 3,24. Hal ini menunjukkan bahwa manajemen sebagai hal yang mendukung promosi (Y) dipersepsikan baik oleh responden. Didukung oleh hasil penelitian bahwa strategi manajemen PR dapat dibagi menjadi tiga, yaitu strategi kerja sama, pencitraan dan promosi (Harlie, 2012; Lugi Basuki, 2016). Peranan PR dalam mengembangkan reputasi PT sangat besar ditentukan oleh kegiatan promosi (Priyatna, 2017; Rahman, 2016). Kegiatan promosi dapat berupa informasi prestasi, penerimaan mahasiswa baru, penyebaran spanduk, pengenalan ke sekolah SMA sederajat, penyebaran brosur, media massa dan promosi lewat door to door. Dari data yang diperoleh berkaitan berkaitan dengan kegiatan promosi tersebut dapat meningkatkan pengetahuan masyarakat dan berkorelasi positif dengan jumlah mahasiswa baru. Berdasarkan hasil responden bahwa peningkatan jumlah mahasiswa yang setuju dan sangat setuju terhadap kegiatan promosi masing-masing $69,9 \%$ dan $27 \%$. hal tersebut menunjukkan bila terdapat responden yang tidak setuju terhadap kegiatan promosi proporsinya sengat kecil yaitu $2,3 \%$.

Hasil uji validitas menggunakan program SPSS untuk masing-masing variabel dengan keputusan bahwa indikator dikatakan valid jika nilai $r$ hitung $>r$ tabel atau sig $<0,05$ dimana $r$ tabel $=\mathrm{r}_{0,05 ; 131}=0,143$, maka dapat diketahui bahwa data yang diperoleh dari item-item pernyataan kuesioner yang digunakan untuk mengukur semua variabel dalam model adalah valid karena semua nilai rhitung $>$ $r$ table (Noviyani, Ketut, Ayu, \& Nyoman, 2016). Selanjutnya adalah uji reabilitas digunakan untuk mengukur suatu kuisioner yang merupakan indikator dari variabel yang konstruk. Suatu kuisioner dikatakan reliabel atau handal apabila jawaban responden atas pernyataan itu konsisten atau stabil dari waktu ke waktu (Janti, 2014). Penentuan tingkat reliabilitas, suatu instrument penelitian dapat diterima bila dalam kisaran Cronbach's Alpha Lebih dari 0,60 sampai dengan 0,80 dianggap baik atau reliabel, serta dalam kisaran lebih dari 0,80 s/d 1,00 dianggap sangat baik atau sangat reliabel. Berikut hasil uji reliabilitas yang terlihat pada Tabel 1 dibawah ini.

Tabel 1. Hasil Uji Reliabilitas

\begin{tabular}{|l|c|l|}
\hline Variabel & $\begin{array}{c}\text { Cronbach's } \\
\text { Alpha }\end{array}$ & Keterangan \\
\hline Manajemen $\left(\mathrm{X}_{1}\right)$ & 0,830 & Reliabel \\
\hline Strategi PR $\left(\mathrm{X}_{2}\right)$ & 0,840 & Reliabel \\
\hline Promosi $(\mathrm{Y})$ & 0,909 & Reliabel \\
\hline
\end{tabular}

Sumber : Data Primer (diolah 2018) 
Berdasarkan pada Tabel 1 maka menunjukkan bahwa semua variabel adalah reliabel karena nilai cronbach's alpha lebih dari 0,60 dan termasuk kategori sangat baik atau sangat reliabel.

Pada pengujian regresi linier berganda dilakukan bersamaan dengan pengujian asumsi klasik. Uji asumsi klasik harus dilakukan karena variabel independennya lebih dari satu, maka perlu diuji keindependenannya. Model regresi linier berganda dapat disebut sebagai model yang baik, jika model tersebut memenuhi asumsi normalitas data dan bebas dari asumsi normalitas data dan bebas dari asumsi klasik statistik, baik itu multikolinearitas, normalitas, dan heteroskedastisitas (Handayani, 2015; Harlie, 2012). Pengujian ini bertujuan untuk menguji apakah di dalam model analisis regresi ditemukan adanya korelasi antar variabel bebas (independen). Model regresi yang baik seharusnya tidak terjadi korelasi diantara variabel independen (Suryani, 2015). Multikolinearitas dapat diketahui dengan cara menganalisis matrik korelasi variabel - variabel independen, dapat dilihat dari variance infaction factor (VIF) dan Tolerance value yang terlihat pada Tabel 2 dibawah ini.

Tabel 2. Hasil Uji Multikolinearitas

\begin{tabular}{|c|c|c|}
\hline Variabel & VIF & Keterangan \\
\hline Manajemen $\left(\mathrm{X}_{1}\right)$ & 3,339 & $\begin{array}{c}\text { Tidak ada } \\
\text { multikolinearitas }\end{array}$ \\
\hline Strategi PR $\left(\mathrm{X}_{2}\right)$ & 3,339 & $\begin{array}{c}\text { Tidak ada } \\
\text { multikolinearitas }\end{array}$ \\
\hline
\end{tabular}

Sumber : Data Primer (diolah 2018)

Berdasarkan pada Tabel 2 maka dapat diketahui bahwa semua nilai VIF pada masing-masing variabel kurang dari 10. Sehingga dapat disimpulkan bahwa tidak ada kasus multikolinearitas.

Uji normalitas bertujuan untuk mengetahui apakah masing-masing variabel berdistribusi normal atau tidak (Kartikasari, 2014; Lugi Basuki, 2016). Uji normalitas diperlukan karena untuk melakukan pengujian-pengujian variabel lainnya dengan mengansumsikan bahwa nilai residual mengikuti distribusi normal. Uji normalitas dalam penelitian ini menggunakan metode KolmogrovSmirnov jika hasil angka signifikansi (Sig) lebih kecil dari 0,05 maka data tidak terdistribusi normal. Uji Kolmogrov Smirnov, dalam uji ini pedoman yang digunakan dalam pengambilan keputusan yaitu dapat disimpulkan bahwa data telah berdistribusi normal karena nilai sig. $>\alpha$ yaitu $0,094>0,05$.

\section{Hubungan Strategi Promosi Terhadap Reputasi Akademi Farmasi Surabaya}

Perencanaan hubungan masyarakat pendidikan merupakan menetapkan kegiatan apa yang ingin dicapai, bagaimana mencapai, berapa lama, berapa orang, dan berapa jumlah biayanya (Sidanti, 2015; Widyaningsih, 2012). Tahap perencanaan ditentukanlah tujuan khusus, prosedur dan strategi, dan pendekatan hubungan masyarakat yang digunakan bagi masing-masing sasaran (Rahman, 2016). Perencanaan hubungan masyarakat dalam pendidikan dapat dibuat berdasarkan rentang waktu yaitu: perencanaan jangka pendek (satu minggu, satu bulan dan satu tahun), perencanaan jangka menengah (2-5 tahun), dan perencanaan jangka panjang (lebih dari 5 tahun). Apabila produsen tidak mampu 
memasarkan hasil produksinya dalam hal ini jasa pendidikan dikarenakan tidak dapat memuaskan konsumen, maka produksi jasa yang ditawarkan tidak akan laku (Aswati, Mulyani, Siagian, \& Syah, 2015; Handayani, 2015). Artinya lembaga pendidikan yang memproses jasa pendidikan tidak mampu memuaska pengguna jasa pendidikan sesuai dengan kebutuhan pasar, bahkan lembaga pendidikan tidak bisa untuk terus eksis. Jadi strategi merupakan suatu langkah dalam memproyeksikan sebuah gagasan yang ditujukan untuk mengapresiasikan tindakan untuk mencapai tujuan, sehingga adanya strategi dapat mempermudah implementasi suatu program dalam mencapai tujuan (Pipin, Mustafid, \& Rochim, 2012; Widyaningsih, 2012; Wijaya, 2015).

Berdasarkan hasil analisis untuk variabel strategi PR maka diperoleh nilai $\mathrm{t}$ hitung sebesar 4,547 dengan signifikan sebesar 0,000. Karena sig. kurang dari 0,05, maka $\mathrm{H}_{0}$ ditolak. Jadi, dapat disimpulkan bahwa strategi PR berpengaruh terhadap promosi.

Strategi PR sangat berperan dalam mempromosikan Akademi Farmasi Surabaya melalui media-media yang digunakan. Terlihat dari hasil jawaban responden yang menyatakan mengetahui dan datang di kampus Akademi Farmasi Surabaya melalui media-media yang dipakai sebagai alat mempromosikan Akademi Farmasi Surabaya bagi masyarakat luas. Perencanaan hubungan masyarakat pendidikan merupakan menetapkan kegiatan apa yang ingin dicapai, bagaimana mencapai, berapa lama, berapa orang, dan berapa jumlah biayanya (Nadlir, 2013; Widyaningsih, 2012). Hal ini bahwa tahap perencanaan ditentukanlah tujuan khusus, prosedur dan strategi, dan pendekatan hubungan masyarakat yang digunakan bagi masing-masing sasaran. Perencanaan hubungan masyarakat dalam pendidikan dapat dibuat berdasarkan rentang waktu yaitu: perencanaan jangka pendek (satu minggu, satu bulan dan satu tahun), perencanaan jangka menengah (2-5 tahun), dan perencanaan jangka panjang (lebih dari 5 tahun). Apabila produsen tidak mampu memasarkan hasil produksinya dalam hal ini jasa pendidikan dikarenakan tidak dapat memuaskan konsumen, maka produksi jasa yang ditawarkan tidak akan laku. Artinya lembaga pendidikan yang memproses jasa pendidikan tidak mampu memuaska pengguna jasa pendidikan sesuai dengan kebutuhan pasar, bahkan lembaga pendidikan tidak bisa untuk terus eksis(Aswati et al., 2015). Jadi strategi merupakan suatu langkah dalam memproyeksikan sebuah gagasan yang ditujukan untuk mengapresiasikan tindakan untuk mencapai tujuan, sehingga adanya strategi dapat mempermudah dalam mengimplementasikan suatu program dalam mencapai tujuan (A. Syakur, 2017).

\section{Hasil analisis Hipotesis strategi PR Berpengaruh Terhadap Promosi Akademi Famasi Surabaya}

Berdasarkan hasil analisis maka diperoleh nilai $\mathrm{F}$ hitung sebesar 111,260 dengan sig. sebesar 0,000. Karena sig. kurang dari 0,05, maka $\mathrm{H}_{0}$ ditolak. Jadi, dapat disimpulkan bahwa manajemen dan strategi PR berpengaruh secara simultan terhadap promosi.

Strategi PR ternyata sangat berperan dalam menjalin hubunga/kerjasama yang baik dengan pihak-pihak lain (Lugi Basuki, 2016). Hal ini dapat dilihat dengan jelas dari srategi PR dengan bekerja sama dengan pihak-pihak lain untuk mempromosikan Akademi Farmasi Surabaya secara tidak langsung melalui pihak- 
pihak lain untuk itulah PR sangat berperan untuk menjalin hubungan yang baik untuk menguntungkan kedua belah pihak. Berdasarkan hasil analisis untuk variabel strategi PR maka diperoleh nilai thitung sebesar 4,547 dengan sig. sebesar 0,000. Karena sig. kurang dari 0,05, maka $\mathrm{H}_{0}$ ditolak. Jadi, dapat disimpulkan bahwa strategi PR berpengaruh terhadap promosi. Berdasarkan hasil analisis maka diperoleh nilai $\mathrm{F}$ hitung sebesar 111,260 dengan sig. sebesar 0,000. Karena sig. kurang dari 0,05 , maka $\mathrm{H}_{0}$ ditolak. Jadi, dapat disimpulkan bahwa manajemen dan strategi PR berpengaruh secara simultan terhadap promosi.

\section{KESIMPULAN}

Kesimpulan dari hasil penelitian ini yaitu strategi PR memiliki peranan yang sangat fundamental dalam membangun reputasi perguruan tinggi Akademi Farmasi Surabaya. Strategi dan managemen PR yang terencana, terstruktur, terorganisir pelaksanaanya memberikan pengaruh secara simultan terhadap perluasan reputasi sehingga memberikan dampak positif terhadap penambahan jumlah minat mahasiswa baru di Akademi Farmasi Surabaya.

\section{SARAN}

Strategi PR hendaknya dilakukan dengan manajemen yang terstruktur, sehingga semua program dapat terlaksana dengan efektif dan berkelanjutan, serta dapat diketahui tingkat kelemahan serta kelebihan dan tingkat pencapaiannya. Mempertahankan hubungan yang sudah baik dengan stakeholder dan tokoh-tokoh masyarakat sekitar untuk mempertahankan eksistensi perguruan tinggi Akademi Farmasi Surabaya di tengah persaingan yang semakin kompetitif berbasis revolusi industri 4.0

\section{DAFTAR RUJUKAN}

Arifin, M. (2017). Strategi Manajemen Perubahan dalam Meningkatkan Disiplin di Perguruan Tinggi. EduTech: Jurnal Ilmu Pendidikan dan Ilmu Sosial, $3(1)$.

Aswati, S., Mulyani, N., Siagian, Y., \& Syah, A. Z. (2015). Peranan sistem informasi dalam perguruan tinggi. JURTEKSI ROYAL Edisi2.

Dirgantari, P. D. (2012). Pengaruh Kualitas Layanan Jasa Pendidikan Terhadap Kepuasan Mahasiswa serta Dampaknya Terhadap Upaya Peningkatan Citra Perguruan Tinggi Negeri Menuju World Class University (Studi pada Mahasiswa Asing di ITB, UNPAD, dan UPI). JURNAL ILMU MANAJEMEN DAN BISNIS, 3(2).

Dirgantari, P. D. (2016). Peranan Bauran Pemasaran Jasa Pendidikan Terhadap Upaya Meningkatkan Ekuitas Merek Berbasis Pelanggan Perguruan Tinggi (Studi Pada Perguruan Tinggi Di Jawa Barat). Strategic: Jurnal Pendidikan Manajemen Bisnis, 16(1), 22-21.

Handayani, T. (2015). Relevansi lulusan perguruan tinggi di Indonesia dengan kebutuhan tenaga kerja di era global. Jurnal Kependudukan Indonesia, 10(1), 53-64.

Harlie, M. (2012). Pengaruh Disiplin Kerja, Motivasi dan Pengembangan Karier terhadap Kinerja Pegawai Negeri Sipil pada Pemerintah Kabupaten Tabalong di Tanjung Kalimantan Selatan. Jurnal Aplikasi Manajemen, 10(4), 860-867. 
Janti, S. (2014). Analisis validitas dan reliabilitas dengan skala likert terhadap pengembangan si/ti dalam penentuan pengambilan keputusan penerapan strategic planning pada industri garmen. Paper presented at the Prosiding Seminar Nasional Aplikasi Sains \& Teknologi (SNAST).

Kartikasari, D. (2014). Analisis Persaingan Pendidikan Tinggi Di Batam Dari Perspektif Politeknik Batam. Jurnal Cakrawala Pendidikan, 33(2).

Lugi Basuki, L. (2016). Strategi Public Relations Event World Sight Day (WSD) Studi Kasus pada Staff di Syamsi Dhuha Foundations (SDF). UIN Sunan Gunung Djati Bandung.

Nadlir, M. (2013). Perencanaan pembelajaran berbasis karakter. Jurnal Pendidikan Agama Islam (Journal of Islamic Education Studies), 1(2), 338-352.

Noviyani, R., Ketut, T., Ayu, I., \& Nyoman, G. (2016). Uji validitas dan reliabilitas kuesioner EORTC QLQ C-30 untuk menilai kualitas hidup pasien kanker ginekologi di RSUP Sanglah Denpasar. Jurnal Farmasi Klinik Indonesia, 5(2), 106-114.

Nur Harini, I. (2014). Manajemen Hubungan Masyarakat dalam Upaya Peningkatan Pencitraan Sekolah (Studi Kasus di SMP Al Hikmah Surabaya). Inspirasi Manajemen Pendidikan, 4(4).

Pipin, W., Mustafid, M., \& Rochim, A. F. (2012). Perencanaan Strategis Sistem Informasi Pada Institusi Pendidikan Tinggi Menggunakan Analisis Critical Success Factors (Studi Kasus: STMIK Duta Bangsa Surakarta). Universitas Diponegoro.

Priyatna, M. (2017). Manajemen pengembangan sdm pada lembaga pendidikan Islam. Edukasi Islami: Jurnal Pendidikan Islam, 5(09), 21.

Rahman, R. S. (2016). Pengaruh Bauran Hubungan Masyarakat (Public Relations Mix) Terhadap Citra Merek Dan Kesadaran Merek Serta Implikasinya Terhadap Keputusan Siswa Memilih Studi. Jurnal Ekonomi, Bisnis \& Entrepreneurship, 10(1), 44-59.

Salim, K., Sari, M. P., Islam, J. M. P., \& Riau, S. A. K. (2014). Pengaruh Globalisasi Terhadap Dunia Pendidikan. Makalah Jurusan Manajemen Pendidikan Islam, STAI Abdurahman Kepulauan Riau. Page, 1-11.

Sidanti, H. (2015). pengaruh lingkungan kerja, disiplin kerja dan motivasi Kerja terhadap kinerja pegawai negeri sipil di Sekretariat DPRD kabupaten madiun. Jurnal Jibeka, 9(1), 44-53.

Suryani, I. (2015). Penanaman Nilai-nilai Anti Korupsi di Lembaga Pendidikan Perguruan Tinggi sebagai Upaya Preventif Pencegahan Korupsi. dalam Jurnal Visi Komunikasi, 14(02), 285-301.

Syakur, A. (2017). Education For Sustainable Development (Esd) Sebagai Respon dari Isu Tantangan Global Melalui Pendidikan Berkarakter dan Berwawasan Lingkungan yang Diterapkan pada Sekolah Dasar, Sekolah Menengah dan Kejuruan di Kota Malang. Eduscience, 1(1), 37-47.

Syakur, A. (2018). Hubungan Kualitas Pelayanan Terhadap Kepuasan Mahasiswa dan Loyalitas Mahasiswa Ditinjau dari Model Pembelajaran di Akademi Farmasi Surabaya. Reformasi: Jurnal Ilmiah Ilmu Sosial dan Ilmu Politik, $8(2), 100-108$.

Widyaningsih, P. (2012). Perencanaan Strategis Sistem Informasi Pada Institusi Pendidikan Tinggi Menggunakan Analisis Critical Success Factors (Studi 
Kasus: STMIK Duta Bangsa Surakarta). Fakultas Sistem Informasi, Universitas Diponegoro Semarang.

Wijaya, I. (2015). Implementasi program corporate social responsibility pt. $x l$ axiata, tbk dalam mengelola reputasi perusahaan (studi kasus program $x l$ future leaders batch 1). Universitas Multimedia Nusantara. 